\title{
PENGARUH QUALITY AWARENESS DAN BRAND IMAGE TERHADAP CUSTOMER SATISFACTION PADA PRODUK WARDAH
}

\author{
Ariza Qanita \\ Universitas Islam Negeri Sunan Ampel Surabaya \\ qanitaariza99@gmail.com \\ Zackya Ulul Albab \\ Universitas Islam Negeri Sunan Ampel Surabaya \\ zackyaulul32@gmail.com
}

\begin{abstract}
Abstrak
Penelitian ini bertujuan untuk menguji pengaruh antara kesadaran kualitas (Quality Awareness) dan citra merek (Brand Image) terhadap kepuasan pelanggan (Customer Satisfaction) pada produk kosmetik Wardah. Metode penelitian yang digunakan adalah kuantitatif dengan teknik analisis regresi linier berganda menggunakan Statistical Process Social Science (SPSS). Objek penelitian ini adalah pengguna kosmetik Wardah dari berbagai jenis produk yang berjumlah sebanyak 71 responden. Hasil penelitian menunjukkan bahwa Quality Awareness dan Brand Image berpengaruh terhadap Customer Satisfaction baik secara parsial maupun secara simultan. Quality awareness berpengaruh signifikan terhadap customer satisfaction dengan koefisien regresi sebesar 0,595. Brand Image berpengaruh signifikan terhadap customer satisfaction dengan koefisien regresi sebesar 0,348. Quality awareness dan brand image secara berkesinambungan berpengaruh terhadap customer satisfaction dan dapat menjelaskan $74,3 \%$ dari variasi variabel customer satisfaction. Wardah sebaiknya lebih mengutamakan penjagaan kualitas karena hal tersebut mempunyai pengaruh yang lebih besar terhadap kepuasan pelanggan.

Keywords: Brand Image; Customer Satisfaction; Quality Awareness.
\end{abstract}

\section{PENDAHULUAN}

Tujuan utama dalam sebuah bisnis adalah untuk mendapatkan profit bagi perusahaan. Bahkan pada hakikatnya, semua manajemen yang diterapkan dalam perusahaan seperti manajemen pemasaran, manajemen kualitas, dan manajemen SDM mengarah pada satu tujuan yang sama yaitu tercapainya tujuan utama perusahaan. Namun tidak hanya manajemen internal perusahaan yang baik, pemenuhan tingkat kepuasan konsumen juga menjadi hal yang sangat penting dan menentukan keberlangsungan usaha. Kepuasan konsumen akan mempengaruhi keputusan pembelian ulang atas produk yang sama hingga menentukan loyalitas pelanggan. Loyalitas pelanggan merupakan aset berharga bagi sebuah perusahaan.

Produk kecantikan merupakan produk yang banyak diminati terutama di kalangan kaum hawa. Perkembangan produk kecantikan pun semakin kompetitif seiring munculnya produk kecantikan dengan berbagai merek. Kompetisi usaha yang semakin ketat membuat nilai kepuasan konsumen menjadi sangat penting. Beberapa usaha yang dilakukan perusahaan untuk memenangkan persaingan adalah dengan menciptakan kualitas produk dan citra merek yang baik. 
Wardah adalah salah satu produk kecantikan yang berdiri sejak tahun 1995 dan telah menjadi produk kosmetik halal nomor satu di Indonesia. Dengan mengusung brand kosmetik halal, wardah semakin banyak diminati kalangan perempuan muslim terutama dengan tren halal lifestyle yang sedang marak belakangan ini. Kesuksesan wardah dalam mengusung brand kosmetik halal mulai diikuti oleh produk lain seperti safi, aishaderm, dan sebagainya. Brand image menjadi hal penting yang diperhatikan perusahaan untuk menarik minat konsumen. Brand image dapat berpengaruh terhadap kepuasan konsumen. Tidak hanya itu, kesadaran konsumen terhadap kualitas produk juga bisa menjadi faktor yang mempengaruhi kepuasan konsumen. Penelitian ini bertujuan untuk mengetahui pengaruh antara kesadaran kualitas (Quality Awareness) dan citra merek (Brand Image) terhadap kepuasan pelanggan (Customer Satisfaction) pada produk kosmetik Wardah baik secara parsial maupun simultan.

\section{KAJIAN PUSTAKA DAN PENGEMBANGAN HIPOTESIS Kesadaran Kualitas (Quality Awareness)}

Kualitas adalah sesuatu yang harus terus menerus ditingkatkan. Secara umum, kualitas dapat diartikan sebagai bagian dari suatu produk barang atau jasa yang harus ada untuk memenuhi keinginan dan ekspektasi pelanggan. Sasaran dari peningkatan kualitas adalah tidak lain untuk memuaskan pelanggan. ${ }^{1}$

Menurut Lewis dan Booms (Besta Adistya A., 2017), kualitas adalah ukuran seberapa bagus pelayanan yang dapat diberikan untuk memenuhi ekspektasi pelanggan. Menurut Kottler dan Amstrong, kualitas produk adalah karakteristik produk barang atau jasa yang ditunjukkan dengan kemampuannya untuk memuaskan kebutuhan pelanggan. Untuk dapat memenuhi kebutuhan pelanggan dan kepuasan konsumen, maka kualitas produk haruslah melekat pada produk yang akan ditawarkan kepada konsumen. Santon berpendapat bahwa kualitas produk adalah suatu jaminan dalam rangka memenuhi kebutuhan konsumen dalam memilih suatu produk dan dalam masalah ini ciri khas pada suatu produk sangat berperan (Inggarrestu Pradiptaningtyas, 2017).

Menurut Simamora, ada dua faktor yang dapat mempengaruhi penilaian kualitas pelayanan. Pertama, expected service adalah apabila layanan yang diterima sesuai dengan yang diharapkan, maka kualitas layanan dipersepsikan memuaskan. Kedua, perceived service adalah apabila layanan yang diterima melampaui keinginan pelanggan, ataupun sebaliknya.

Quality Awareness (Kesadaran akan Kualitas) adalah sebuah bagian dari sistem kualitas. Maksudnya adalah memberi pemahaman kepada orang awam tentang dasar-dasar dari kualitas, sehingga mereka tidak salah paham dengan aspek-

\footnotetext{
${ }^{1}$ Kashif Hussain, dkk.,A Quality Awareness Approach For The Industry, (Universite de Valenciennes et du Hainaut de Cambresis, Valenciennes, France: IFAC, 2006), hlm. 2
} 
aspek kualitas dan dapat menilai bagaimana kualitas pada suatu produk barang atau jasa.

Urgensi kesadaran kualitas dapat dipahami melalui dua nilai yaitu nilai kualitas dan nilai non kualitas. Nilai non kualitas seperti penanganan risiko, banyaknya waktu untuk mengcover segala efek samping dari peningkatan kualitas. Kesadaran kualitas berkaitan dengan hal-hal umum yang ada pada perusahaan yaitu kualitas pelayanan dan kepuasan pelanggan. Untuk memenuhi kedua hal tersebut, karyawan akan meingkatkan komunikasi, kerjasama dan pembelajaran yang akan berdampak baik pada perusahaan. Pada dasarnya tujuan dari kesadaran akan kualitas adalah untuk meingkatkan kerjasama tim dan memberitahukan kepada karyawan tentang langkah-langkah dalam improvement perusahaan di masa yang akan datang.

Pentingnya memberikan kualitas produk yang baik turut mempengaruhi kepuasan pelanggan. Berdasarkan penelitian yang dilakukan oleh Christian Lasander menunjukkan bahwa kualitas produk berpengaruh signifikan terhadap kepuasan konsumen (Lasander, 2013).

H1: Quality Awareness berpengaruh positif terhadap Customer Satisfaction

\section{Citra Merek (Brand Image)}

Citra merek atau brand image merupakan persepsi konsumen atas suatu produk tertentu. Menurut Keller (Fanny Fibriyanti Salim, 2014) citra merek adalah persepsi konsumen tentang suatu merek sebagai refleksi dari asosiasi merek yang ada pada pikiran konsumen. Sedangkan menurut Kotler (Dewi Kurniawati, 2014) citra merek adalah penglihatan dan kepercayaan yang terpendam dalam benak konsumen sebagai cerminan asosiasi yang tertahan di ingatan konsumen. Citra merek menjadi suatu ciri khas yang dapat dikenali dan melekat pada ingatan konsumen.

Brand image yang baik dapat menjadi salah satu strategi untuk menarik minat konsumen. Semakin baik brand image suatu produk, maka persepsi konsumen atas produk tersebut juga akan semakin tinggi. Persepsi dapat diartikan sebagai harapan-harapan yang ingin didapatkan konsumen dari mengkonsumsi suatu produk. Semakin baik suatu merek dapat memenuhi persepsi konsumen, maka tingkat kepuasan konsumen juga akan semakin tinggi. Kuatnya brand image di benak konsumen akan menyebabkan semakin kuat rasa percaya diri yang dirasakan oleh konsumen dalam menggunakan produk yang dibelinya. Rasa percaya diri yang tinggi ini menandakan bahwa konsumen tersebut merasa puas dengan produk yang dibelinya.

Menurut Biel's (Dewi Kurniawati, 2014) brand image terdiri dari tiga komponen yaitu Citra Perusahaan (Corporate Image), Citra Pemakai (User Image), dan Citra Produk (Product Image). Sementara Keller mengemukakan bahwa brand image dapat diklasifikasikan menjadi functionalbenefit, symbolic benefit, experiental benefit, socialbenefit, dan appearance enhances. Functional benefits 
memiliki hubungan secara intrinsik dengan keuntungan konsumsi sebuah produk barang atau jasa dan juga memiliki korespondensi dengan atribut produk. Experiential benefits membahas mengenai apa yang dirasakan pelanggan setelah memakai produk barang atau jasa dan berkorespondensi ke atribut produk tersebut. Kemudian, symbolic benefits berkaitan dengan menekankan pada kebutuhan sosial atau ekspresi individu dan pada dasarnya berkaitan dengan nonproductrelated attributes (Fanny Fibriyanti Salim, 2014).

Pengukuran terhadap citra merek dapat dilakukan melalui tiga aspek yaitu kekuatan (strengthnes), keunikan (uniqueness), dan favorable (Radita Herliza, 2016). Semakin baik persepsi di benak konsumen terhadap citra merek perusahaan, maka kepuasan konsumen juga akan semakin tinggi. Sebaliknya, jika persepsi konsumen terhadap citra merek buruk, maka kepuasan konsumen juga akan semakin rendah. Kepusaan pelanggan itu dapat diciptakan karena apa yang mereka rasakan sesuai atau malah lebih dari yang diharapkan.

Berdasarkan penelitian yang dilakukan oleh Balqis Diab menunjukkan bahwa citra merek berpengaruh signifikan terhadap kepuasan pelanggan (Diab, 2009). Penelitian serupa yang dilakukan oleh Eugenia menunjukkan hasil bahwa citra merek berpengaruh positif dan signifikan terhadap kepuasan pelanggan pada Klinik Kecantikan Cosmedic (Eugenia Andrea Dennisa, 2016).

$\mathrm{H} 2$ : Brand Image berpengaruh positif terhadap Customer Satisfaction

\section{Kepuasan Pelanggan (Customer Satisfaction)}

Customer satisfaction pada hakikatnya merupakan tingkat terpenuhinya persepsi konsumen atas produk yang dikonsumsi. Menurut Philip Kotler (Fanny Fibriyanti Salim, 2014) kepuasan konsumen (consumen's satisfaction) adalah tingkat perasaan seseorang setelah membandingkan kinerja atau hasil yang dirasakan dibandingkan dengan harapan. Semakin terpenuhi persepsi konsumen atas produk yang dikonsumsi, maka kepuasan konsumen juga akan semakin meningkat. Begitupun sebaliknya, jika persepsi konsumen atas produk tidak terpenuhi dengan baik, maka konsumen akan merasa kecewa.

Menurut Tjiptono (Radita Herliza, 2016) terdapat 6 aspek penting untuk mengukur kepuasan pelanggan, yaitu:

a. Kepuasan keseluruhan (overall satisfaction)

b. Konfirmasi harapan (confirmation of expectation)

c. Minat pembelian ulang

d. Dimensi kepuasan pelanggan

e. Ketidakpuasan pelanggan

f. Kesediaan untuk merekomendasi

Kepuasan konsumen merupakan hal yang sangat penting untuk dicapai sebuah perusahaan. Konsumen yang puas terhadap sebuah produk akan menciptakan loyalitas dalam waktu yang cukup lama, melakukan pembelian ulang atas produk yang sama, komunikasi positif atau rekomendasi kepada orang lain 
terkait produk, serta tidak terlalu sensitif terhadap perubahan harga dan tidak mudah beralih kepada produk pesaing. Bahkan faktor-faktor yang mendorong terciptanya kepuasan pelanggan juga dapat berpengaruh pada keputusan pembelian. Hal ini sesuai dengan penelitian terdahulu yang dilakukan oleh Rizky menunjukkan bahwa citra merek dan kualitas produk berpengaruh secara simultan terhadap keputusan pembelian (Rizky Desty Wulandari, 2018).

H3: Quality Awareness dan Brand Image berpengaruh secara simultan terhadap Customer Satisfaction

\section{METODE PENELITIAN}

Jenis penelitian ini adalah kuantitatif. Objek penelitian adalah pengguna kosmetik Wardah dari berbagai jenis produk. Teknik pengumpulan data dilakukan melalui kuisioner terhadap 71 responden. Teknik analisis data menggunakan regresi linier berganda dengan quality awareness sebagai variabel X1 dan brand image sebagai variabel X2 dan customer satisfaction sebagai variabel Y.

\section{HASIL DAN PEMBAHASAN}

Produk kosmetik Wardah merupakan salah satu merek produk kosmetik tanah air yang di produksi oleh PT. Pustaka Tradisi Ibu yang berganti nama menjadi PT Paragon Technology and Innovation (PTI) pada tahun 2011. Perusahaan yang bergerak di bidang kosmetika ini didirikan oleh pasangan suami-istri Drs. H. Subakat Hadi, M.Sc dan Dra. Hj. Nurhayati Subakat, Apt. pada tanggal 28 Februari 1985. Produk kosmetik yang pertama kali di produksi oleh perusahaan adalah produk perawatan rambut. Pada tahun 1987, perusahaan ini memproduksi produk perawatan rambut dengan merek Ega yang lingkup pemasarannya adalah salonsalon. Kemudian lahirlah produk Putri yang sampai sekarang masih diproduksi. Produk utama dari Putri adalah shampoo, yang kemudian berkembang menjadi produksi obat keriting, creambath, hairtonic, hairspray, dan produk perawatan rambut lainnya.

Pada tahun 1995, PTI kedatangan santri-santri dari pesantren Hidayatullah yang menginginkan PTI memproduksi kosmetika yang berlandaskan syariat dan bernafaskan Islami. Adanya permintaan dari santri- santri tersebut kemudian lahirlah produk kosmetik Wardah dengan positioning kosmetik halal dan aman. Dikatakan halal karena produknya telah memiliki sertifikat halal dari LPPOM MUI dan aman karena memakai bahan baku bermutu tinggi dan telah memiliki nomor registrasi yang dikeluarkan oleh Departemen Kesehatan. Pada tahun 1995, Wardah masih belum bisa berkembang dikarenakan manajemennya masih kurang baik. Pada tahun 1996, PTI kembali mencoba mengembangkan produk kosmetik Wardah. Sejak itu penjualannya mulai menanjak dan PTI memasuki pasar tata rias (decorative). Pada tahun 1999-2003, PTI mengalami perkembangan kedua. Penjualan produk kosmetik Wardah pada masa tersebut melonjak pesat. Pada tahun 2002-2003 PTI mulai memodernisasi perusahaannya. 
Produk kosmetik Wardah telah memasuki retail yang memerlukan perubahan dari segi internal. Selain telah memasuki retail, produk kosmetik Wardah juga melakukan promosi dengan melakukan periklanan/advertising di berbagai media untuk mengenalkan produk-produknya ke pasar sasaran. Pada tahun 2005, PTI sudah menerapkan Good Manufacturing Practice (GMP) dan Cara Pembuatan Kosmetika yang Baik (CPKB). Pada tahun 2007, produk range kosmetik Wardah semakin lengkap. Dari tahun ke tahun perkembangan produk kosmetik Wardah semakin meningkat. Di tengah banyaknya persaingan dari perusahaan-perusahaan yang bergerak di bidang kosmetika, diperlukan adanya semacam inovasi terhadap produk-produknya untuk menarik minat konsumen. Sehingga pada tahun 2009, produk kosmetik Wardah re-launch dengan kemasan baru (Wardah New Look). Tahun 2009 hingga tahun 2013 merupakan tahun-tahun keemasan bagi produk kosmetik Wardah. Pada tahun 2011, produk kosmetik Wardah menerima Halal Award 2011 untuk kategori Brand Kosmetik Halal. Tidak hanya itu, Wardah juga mengikuti Halal \&Healthy Products Fair di CNR Expo, Istanbul - Turki. Pada tahun 2011 ini juga, Store Wardah pertama dibuka di fX Sudirman, Jakarta. Selain keberhasilan-keberhasilan yang telah diraih di atas, Wardah mendapatkan penghargaan The 2nd Indonesia Original Brand (IOB) 2011 versi majalah SWA. Pada tahun 2012, Wardah kembali meraih penghargaan The 1st Indonesia Original Brand tahun 2012 versi majalah SWA. Pada tahun 2012 ini pula, Wardah membuka outlet sekaligus Store Wardah pertama di Malaysia. Pada tahun 2013, Wardah sudah membuka 22.000 outlet di Indonesia dan Malaysia. Wardah juga menjadi The 1st local brand dengan penjualan tertinggi di Matahari Departemen store dan menduduki ranking 3 dari seluruh brand (lokal dan global).

Wardah sudah memiliki citra merek yang baik sebagai kosmetik halal. Namun kepuasan pelanggan tidak hanya ditentukan dari citra merek melainkan juga dari kualitas produk. Penelitian ini bertujuan untuk mengetahui dan membandingkan pengaruh antara citra merek dan kualitas produk dilihat dari persepsi konsumen kaitannya dengan kepuasan mereka dalam mengkonsumsi produk Wardah. Berdasarkan analisis menggunakan regresi linier berganda, maka diperoleh hasil sebagai berikut:

Tabel 1. Hasil Uji T Coefficients $^{\mathrm{a}}$

\begin{tabular}{|c|c|c|c|c|c|c|}
\hline \multirow{2}{*}{\multicolumn{2}{|c|}{ Model }} & \multicolumn{2}{|c|}{$\begin{array}{c}\text { Unstandardized } \\
\text { Coefficients }\end{array}$} & \multirow{2}{*}{\begin{tabular}{|c}
$\begin{array}{c}\text { Standardiz } \\
\text { ed } \\
\text { Coefficients }\end{array}$ \\
Beta \\
\end{tabular}} & \multirow[b]{2}{*}{$\mathrm{T}$} & \multirow[b]{2}{*}{ Sig. } \\
\hline & & $\mathrm{B}$ & Std. Error & & & \\
\hline \multirow[t]{3}{*}{1} & (Constant) & $-3,207$ & 1,312 & & $-2,444$ &, 017 \\
\hline & $\begin{array}{l}\text { QualityAwar } \\
\text { eness(X1) }\end{array}$ & ,595 & ,072 & ,654 & 8,262 & ,000 \\
\hline & $\begin{array}{l}\text { Brandlmage } \\
\text { (X2) }\end{array}$ & ,348 & ,097 & ,285 & 3,599 & ,001 \\
\hline
\end{tabular}


a. Dependent Variable: CustomerSatisfaction(Y)

Uji $\mathrm{T}$ dilakukan untuk mengetahui pengaruh variabel-variabel independen secara individual terhadap variabel dependen. Dasar pengambilan keputusan pada uji t adalah jika nilai sig $<0,05$ maka tolak $\mathrm{H} 0$ dan terima $\mathrm{H} 1$ yang artinya terdapat pengaruh variabel $\mathrm{X}$ terhadap variabel $\mathrm{Y}$. Sedangkan jika nilai sig > 0,05 maka terima $\mathrm{H} 0$ dan tolak $\mathrm{H} 1$ yang artinya tidak terdapat pengaruh variabel $\mathrm{X}$ terhadap variabel Y. Dalam penelitian ini, quality awareness memiliki nilai sig sebesar 0,000 $<0,05$ berarti quality awareness berpengaruh terhadap customer satisfaction. Sementara variabel brand image memiliki nilai sig sebesar 0,001 $<0,05$ berarti brand image berpengaruh terhadap customer satisfaction.

Tabel 2 Hasil Uji F

ANOVA ${ }^{a}$

\begin{tabular}{|l|r|r|r|c|c|}
\hline Model & \multicolumn{1}{|c|}{$\begin{array}{c}\text { Sum of } \\
\text { Squares }\end{array}$} & Df & $\begin{array}{c}\text { Mean } \\
\text { Square }\end{array}$ & F & \multicolumn{1}{c|}{ Sig. } \\
\hline $1 \quad$ Regression & 339,852 & 2 & 169,926 & 98,553 &, $000^{\mathrm{b}}$ \\
Residual & 117,246 & 68 & 1,724 & & \\
Total & 457,099 & 70 & & & \\
\hline
\end{tabular}

a. Dependent Variable: CustomerSatisfaction(Y)

b. Predictors: (Constant), Brandlmage(X2), QualityAwareness(X1)

Uji F dilakukan untuk menguji pengaruh antara variabel-variabel independen secara simultan atau keseluruhan terhadap variabel dependen. Dalam penelitian ini, quality awareness dan brand image berpengaruh secara simultan terhadap customer satisfaction yang ditunjukkan dengan nilai sig sebesar $0,000<0,05$.

Tabel 3 Hasil Koefisien Determinasi Model Summary

\begin{tabular}{l|c|r|r|r|}
\hline Model & $\mathrm{R}$ & R Square & $\begin{array}{c}\text { Adjusted R } \\
\text { Square }\end{array}$ & $\begin{array}{c}\text { Std. Error of the } \\
\text { Estimate }\end{array}$ \\
\hline 1 &, $862^{\mathrm{a}}$ &, 743 &, 736 & 1,313 \\
\hline a. Predictors: & (Constant), & Brandlmage(X2), \\
QualityAwareness(X1) & \multicolumn{4}{|c|}{}
\end{tabular}

Koefisien determinasi menunjukkan seberapa jauh variabel-variabel independen dapat menjelaskan variasi variabel dependen. Penilaian ini dilihat dari nilai $\mathrm{R}$ square. Berdasarkan out put di atas diketahui nilai $R$ square sebesar 0,743. Hal ini berarti bahwa variabel quality awareness dan brand image secara simultan dapat menjelaskan customer satisfaction sebesar $74,3 \%$, sementara $25,7 \%$ sisanya dijelaskan oleh variabel lain di luar model. 


\section{Pengaruh Quality Awareness terhadap Customer Satisfaction}

Menurut uji T, quality awareness memiliki nilai sig sebesar 0,000 0,05 berarti quality awareness berpengaruh terhadap customer satisfaction. Hal ini sesuai dengan teori, bahwa quality awareness berpengaruh terhadap customer satisfication. Terbuktinya hipotesis ini dapat memberikan informasi bahwa semakin baik quality awareness pada suatu produk, maka customer satisfication pada suatu produk juga semakin meningkat, begitu juga sebaliknya, semakin buruk quality awareness pada suatu produk, maka customer satisfication pada suatu produk juga akan semakin menurun.

\section{Pengaruh Brand Image terhadap Customer Satisfaction}

Dalam penelitian ini, variabel brand image memiliki nilai sig sebesar 0,001 $<0,05$ berarti brand image berpengaruh terhadap customer satisfaction. Dengan terbuktinya hipotesis ini dapat diambil kesimpulan bahwa semakin baiknya brand image pada suatu produk maka customer satisfication akan tinggi, dan berlaku sebaliknya, semakin buruknya brand image suatu produk maka customer satisfication akan rendah.

\section{Pengaruh Quality Awareness dan Brand Image terhadap Customer Satisfaction}

Dalam penelitian ini, quality awareness dan brand image berpengaruh secara simultan terhadap customer satisfaction yang ditunjukkan dengan nilai sig sebesar $0,000<0,05$. Diketahui nilai $\mathrm{R}$ square di atas adalah sebesar 0,743 . Hal ini menunjukkan bahwa variabel quality awareness dan brand image secara simultan dapat menjelaskan customer satisfaction sebesar 74,3\%, sementara 25,7\% sisanya dijelaskan oleh variabel lain di luar model. Terbuktinya hipotesis ini menunjukkan bahwa quality awareness dan brand image pada suatu produk, secara bersamaan akan mempengaruhi customer satisfaction

\section{KESIMPULAN}

Quality awareness berpengaruh signifikan terhadap customer satisfaction. Koefisien regresi quality awareness sebesar 0,595 menunjukkan bahwa setiap bertambahnya kesadaran kualitas pelanggan sebesar 1000 akan meningkatkan kepuasan pelanggan atau customer satisfaction sebesar 595. Brand Image berpengaruh signifikan terhadap customer satisfaction. Koefisien regresi brand image sebesar 0,348 menunjukkan bahwa setiap bertambahnya citra merek sebesar 1000 akan meningkatkan kepuasan pelanggan atau customer satisfaction sebesar 348. Quality awareness dan brand image secara berkesinambungan berpengaruh terhadap customer satisfaction. Quality awaraness dan brand image dapat menjelaskan $74,3 \%$ dari variasi variabel customer satisfaction. Sedangkan 25,7\% dijelaskan oleh variabel lain di luar model. 
Selain mengembangkan citra merek, sebaiknya produk Wardah juga terus memperhatikan kualitas produk karena faktor ini memiliki pengaruh yang lebih tinggi terhadap kepuasan pelanggan. Hasil penelitian ini kurang lebih sudah sesuai dengan penelitian-penelitian terdahulu. Namun, penulis menyadari bahwa dalam penelitian ini juga masih terdapat banyak kekurangan karena keterbatasan waktu penelitian. Untuk penelitian selanjutnya, penulis menyarankan untuk melakukan penambahan sampel agar hasil penelitian lebih kongkrit atau bisa menambahkan variabel-variabel lain yang belum dimasukkan dalam model. 


\section{DAFTAR PUSTAKA}

Besta Adistya A., D. A. (2017). Pengaruh Kesadaran Merek dan Kualitas Pelayanan Terhadap Keputusan Pembelian (Pada Peacock Coffe di Jalan Gajah Mada Semarang). Skripsi, Universitas Diponegoro, Semarang.

Dewi Kurniawati, S. A. (2014). Pengaruh Citra Merek dan Kualitas Produk Terhadap Kepuasan dan Loyalitas Pelanggan. Jurnal Administrasi Bisnis , 14 (2).

Diab, B. (2009). Analisis Pengaruh Nilai Pelanggan dan Citra Merek Terhadap Kepuasan Pelanggan Dalam Meningkatkan Retensi Pelanggan. Tesis, Universitas Diponegoro, Magister Manajemen, Semarang.

Eugenia Andrea Dennisa, S. B. (2016). Analisis Pengaruh Kualitas Produk, Kualitas Layanan, dan Citra Merek Terhadap Loyalitas Pelanggan Melalui Kepuasan Konsumen Pelanggan Sebagai Variabel Intervening (Studi Pada Klinik Kecantikan Cosmedic Semarang). Diponegoro Journal of Management , 5 (3).

Fanny Fibriyanti Salim, D. D. (2014). Pengaruh Brand Image dan Perceived Quality Terhadap Kepuasan dan Loyalitas Pelanggan Mobil Toyota Surabaya. Jurnal Manajemen Pemasaran Petra, 2 (1).

Inggarrestu Pradiptaningtyas, A. H. (2017). Pengaruh Kesadaran Merek, Assosiasi Merek, dan Kualitas Produk Terhadap Keputusan Pembelian Konsumen Minute Maid Pulpy (Studi Pada Konsumen Minute Maid Pulpy di Kecamatan Banyumanik). Skripsi, Universitas Diponegoro, Semarang.

Lasander, C. (2013). Citra Merek, Kualitas Produk dan Promosi Pengaruhnya Terhadap Kepuasan Konsumen Pada Makanan Tradisional (Survey Pada Industri Rumah Tangga Dodol Daging Pala Audia di Tahuna Kab. Sangihe). Jurnal EMBA, 01 (03).

Radita Herliza, M. E. (2016). Pengaruh Brand Image Terhadap Kepuasan Pelanggan Studi Pada Zara di Mall PVJ Bandung. e-Proceeding of Management, 3 .

Rizky Desty Wulandari, D. A. (2018). Pengaruh Citra Merek dan Kualitas Produk Terhadap Keputusan Pembelian Pada Produk Kosmetik. Jurnal Riset Manajemen dan Bisnis , 3 (1). 